\title{
Redescription of little known Carpenter-Moths species Eremocossus foedus (Swinhoe, 1884) (Lepidoptera: Cossidae)
}

\author{
Переописание малоизвестного вида древоточџев Eremocossus \\ foedus (Swinhoe, 1884) (Lepidoptera: Cossidae)
}

\author{
R.V. Yakovlev \\ P.В. Яковлев
}

\begin{abstract}
Altai State University, pr. Lenina 61, Barnaul, 656049, Russia.
PaleoData Lab, Institute of Archaeology and Ethnography SB RAS, Novosibirsk, Russia. E-mail: yakovlev_asu@mail.ru Алтайский государственный университет, пр. Ленина 61, Барнаул 656049, Россия.

Лаборатория «PaleoData», Институт археологии и этнографии CO РAН, Новосибирск, Россия.
\end{abstract}

KEY WORDS: entomology, biodiversity, Carpenter moths, fauna, Pakistan.

КЛЮЧЕВЫЕ СЛОВА: энтомология, биоразнообразие, древоточцы, фауна, Пакистан.

ABSTRACT. The article gives a redescription of a little known species, Eremocossus foedus (Swinhoe, 1884). For the first time, the description of male genitalia is provided, the detailed description of the external characters is given, the established differential diagnosis allows to distinguish the described species from close species of the genus Eremocossus Hampson, 1892.

РЕЗЮМЕ. В статье представлено переописание малоизвестного вида Eremocossus foedus (Swinhoe, 1884). Впервые описаны гениталии самца, дано детальное описание внешних характеристик, приведён дифференциальный диагноз от близких видов рода Eremocossus Hampson, 1892.

The genus Eremocossus was established by Hampson [1892: 313] for the species Phragmataecia foeda Swinhoe, 1884, described from southern Pakistan (Karachi). Swinhoe [1884] erroneously attributed the described species to the genus Phragmataecia, belonging to the subfamily Zeuzerinae. Additionally, probably due to a misprint, this species was placed into the family Notodontidae [Swinhoe, 1884: 515]. Later, from the desert regions of the western Palaearctic (from Morocco and southern Spain in the west to Armenia in the east) a series of taxa was described [Staudinger, 1897a, b, 1899; Püngeler, 1899; Lucas, 1907; Le Cerf, 1919; Turati, 1930; Rebel, 1935; Krüger, 1939; Daniel, 1949; Rungs, 1951; de Freina, Witt, 1990; Yakovlev, 2008, 2019]. The status of some forms has not been revised. The type species of the genus Eremocossus has not been studied morphologically.
Examining the materials deposited in the collections of Natural History Museum (London, Great Britain) and Naturhistorisches Museum (Wien, Austria) we studied the holotype (male) and the topotypes (males) of $E$. foedus (Swinhoe, 1884) [Yakovlev, Witt, 2016]. The male genitalia slides [Lafontaine, 2004] were examined with an Olympus SZX16 microscope. The images were taken with the Olympus SZX16 camera. The genitalia and imago images were processed using Corel Draw software.

To establish the diagnosis, all valid species and subspecies of the genus were examined: E. vaulogeri blanca (Daniel, 1949) and E. nubica Yakovlev, 2008 (holotype deposited in the Zoologische Staatssammlung der Bayerischen Staaten, Munich, Germany), E. vaulogeri (Staudinger, 1897), E. vaulogeri jordana (Staudinger, 1897), and E. asema (Püngeler, 1899) (cotypes deposited in the Museum für Naturkunde, Leibniz Institut für Evolution und Biodiversitatsforschung, Berlin, Germany), $E$. vaulogeri senegalensis Le Cerf, 1919 and E. vaulogeri meirleirei (Rungs, 1951) (holotypes deposited in the Muséum National d'Histoire Naturelle, Paris, France), $E$. erebuni Yakovlev, 2008 (holotype deposited in Zoological Institute, St. Petersburg, Russia), and E. almeriana (de Freina, Witt, 1990) (holotype deposited in Museum Witt, Munich, Germany).

\section{Eremocossus foedus (Swinhoe, 1884)}

Figs 1-4.

Phragmataecia foeda Swinhoe, 1884: 515.

Type locality: Kurrachee [Karachi, Southern Pakistan].

MATERIAL. Holotype, male (slide Coss-255) (Natural History Museum, London, Great Britain); 1 male, Karachi, 14.iv.[19]06, T.R. Bell (individual number NHMUK 012832436; slide 010315469,

How to cite this article: Yakovlev R.V. 2021. Redescription of little known Carpenter-Moths species Eremocossus foedus (Swinhoe, 1884) (Lepidoptera: Cossidae) // Russian Entomol. J. Vol.30. No.1. P.100-102. doi: 10.15298/rusentj.30.1.12 


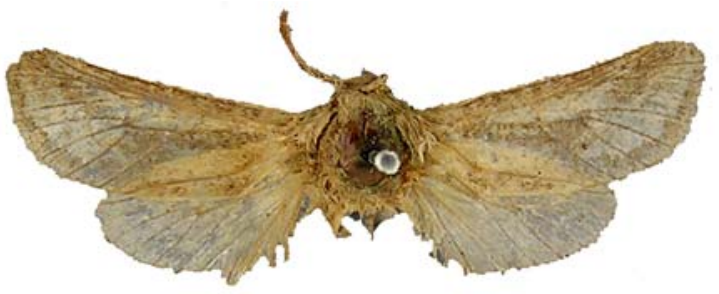

1

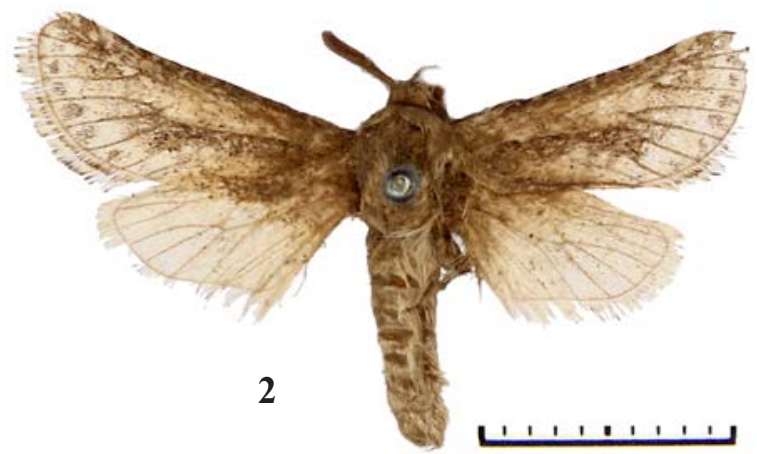

Figs 1-2. Eremocossus foedus, males (Natural History Museum. London): 1 - Holotype; 2 - ex. from Karachi, 14.iv.[19]06, T.R. Bell.

Рис. 1-2. Eremocossus foedus, самцы (Музей естественной истории, Лондон): 1 - голотип; 2 - экземпляр из Карачи, 14.iv.[19]06, T.R. Bell.

(Natural History Museum, London, Great Britain)); 1 male, Karachi, Umgbg. Flughafen, 23.02-9.03.1961, E. \& A. Vartian (Naturhistorisches Museum, Wien, Austria).

Redescription. Size medium, length of male fore wing 11-12 mm. Antenna bipectinate, crest processes twice long- er than antenna rod diameter. Fore wing light-yellow, from root to discal area a light-brown portion with enlightenment in central cell and brown strokes marginally between veins. Fringe yellow with single brown scales. Hind wing lightyellow without pattern, fringe yellow.

Male genitalia. Typical for the genus Eremocossus. Uncus wide, conical, apically semicircular; gnathos arms long, thin; gnathos ribbon-like, flat; valve relatively short, distal third membranous, lanceolate, small semicircular process on costal edge of valve (on border between sclerotized and membranous part); transtilla processes short, uncinately curved; juxta tiny, with two tapered lateral processes; saccus large, semicircular; phallus equal to valve in length, basally thick, gradually narrowing to apex, apex obliquely cut, vesica aperture in dorso-apical position, takes about $1 / 3$ of phallus in length.

Diagnosis. In the color, E. foedus is mostly close to the nominative subspecies, E. vaulogeri (Staudinger, 1897), from which it differs in a less bright coloring and in the male genital structure: the uncinately curves transtilla processes (which are straight in E. vaulogeri), in the wider apex of the valve (in $E$. vaulogeri the apex is strongly narrowing), and in the smooth apex of the phallus (in E. vaulogeri there are small paired denticles at the apex pf the phallus near the vesica aperture).

Flight period. January-April.

Acknowledgements. The author is grateful to Anna Ustjuzhanina (Tomsk, Russia) for linguistic improvements, and to X. Proskuryakova (Moscow, Russia) for the assistance in making genital preparations. The author is cordially thankful to all who helped him to prepare this work: $\dagger$ Th. Witt (Munich), A. Hausmann (Munich), W. Mey (Berlin), S. Sinev (St. Petersburg), G. Martin and A. Giusti (London), and J. Minet (Paris). The author expresses his gratitude to the council of trustees of Natural History Museum (London) for the kind permission to publish the images of the type specimens.
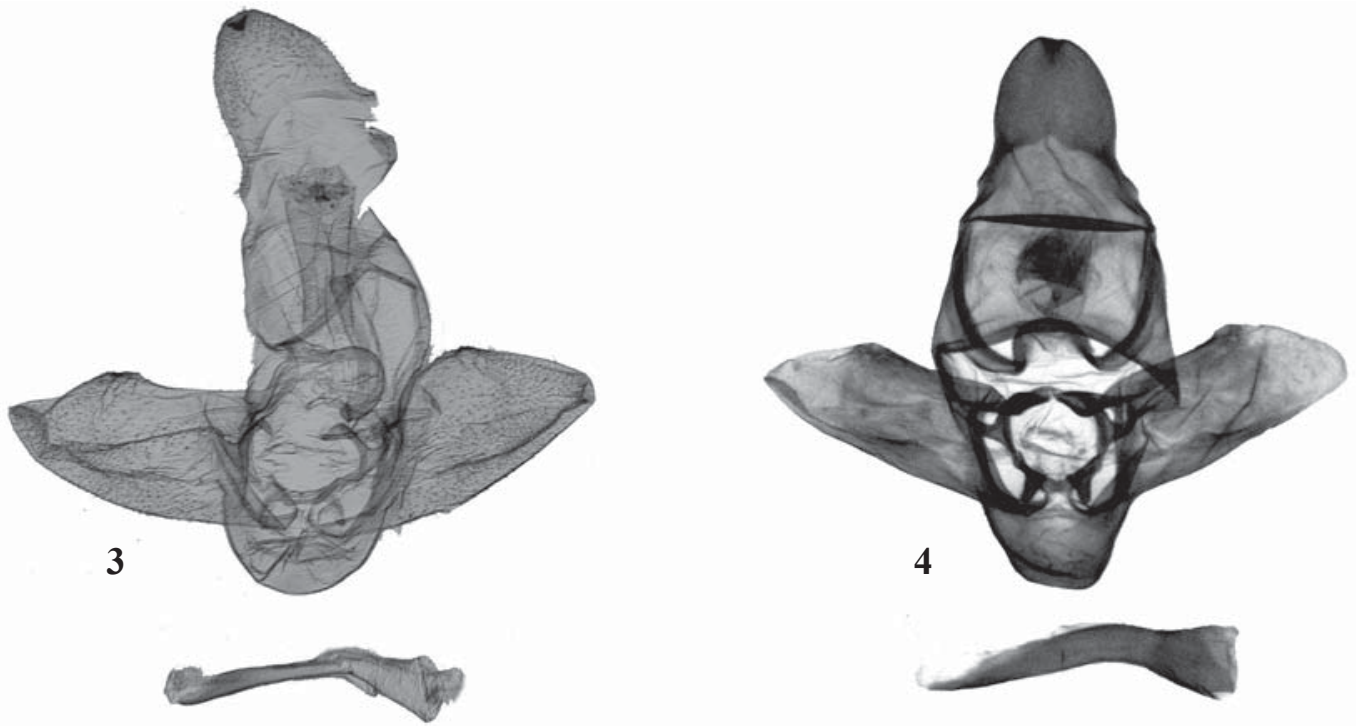

Figs 3-4. Male genitalia of E. foedus: 3 - Holotype (slide Coss-255); 4 - ex. Karachi, 14.iv.[19]06, T.R. Bell (slide 010315469). Рис. 3-4. Гениталии самцов E. foedus: 3 - голотип (препарат Coss-255); 2 - экземпляр из Карачи, 14.iv.[19]06, T.R. Bell (препарат 010315469). 


\section{References}

Daniel F. 1949. Neue palaearktische Heterocera (Lep.) // Mitteilungen der Münchner Entomologischen Gesellschaft. Bd.35-39. S.235-241.

de Freina J.J., Witt Th.J. 1990. Zur Sytematik des paneremisch verbreiteten Dyspessa foeda-vaulogeri-Komplexes mit Beschreibung einer neuen Unterart aus Südostspanien (Lep. Cossidae) // Nachrichtenblatt der Bayerischen Entomologen. Bd.39. No.1. S.20-25.

Hampson G.F. 1892. Moths. Vol.I // The fauna of British India including Ceylon and Burma. Dr. W. Junk b.v. Publishers, The Hague. 527 p.

Krüger G.C. 1939. Notizie sulla Fauna della Sirtica Occidentale: Lepidopteri // Annali del Museo Libico di Storia natural. T.1. P.317-357.

Lafontaine J.D. 2004. Noctuoidea, Noctuidae (part), Noctuinae (part-Agrotini) // R.W. Hodges (ed.). The Moths of America North of Mexico. Washington: The Wedge Entomological Research Foundation. Fasc.27.1. P.1-385.

Le Cerf F. 1919. Lépidoptères nouveaux de la Collection du Muséum National d'Histoire Naturelle de Paris // Bulletin du Museìum national d'histoire naturelle. T.25. P.27-29.

Lucas D. 1907. Description de trois Lépidoptères nouveaux d'Algerie et de Tunisie // Bulletin de la Société entomologique de France. Année 1907. T.12. No.12. P.196-198.
Püngeler R. 1899. Neue Macrolepidopteren aus Central-Asien // Deutsche Entomologische Zeitschrift "Iris". Bd.12. S.288-299.

Rebel H. 1935. Eine neue Cossidae aus Tunis // Zeitschrift des Österreichischen Entomologischen Vereins. Bd.20. S.19-20.

Rungs Ch. 1951. Notes de lépidoptérologie Marocaine (XVIII). Nouvelles formes et espèces rares du Maroc // Bulletin de la Société des sciences naturelles du Maroc. T.31. P.75-92.

Staudinger O. 1897a. Drei neue paläarktische Lepidopteren // Deutsche Entomologische Zeitschrift "Iris". Bd.10. S.153-156.

Staudinger O. 1897b. Neue Lepidopteren aus Palaestina // Deutsche Entomologische Zeitschrift "Iris". Bd.10. S.271-319.

Staudinger O. 1899 Neue Lepidopteren des palaearktischen Faunengebiets // Deutsche Entomologische Zeitschrift "Iris". Bd.12. S.352-403.

Swinhoe C. 1884. On Lepidoptera collected at Kurrachee // Proceedings Zoological Society London. Vol.1884. P.503-515.

Turati E. 1930. Novita di Lepitotterologia in Cirenaica. III // Atti della Società Italiana di Scienze Naturali e del Museo Civico di Storia Naturale in Milano. T.69. No.1. P.46-92.

Yakovlev R.V. 2008. Notes about the Genus Eremocossus Hampson, 1892 (Lepidoptera, Cossidae) // Atalanta. Bd.39. P.404411.

Yakovlev R.V. 2019. Eremocossus erebuni Yakovlev, 2008, stat.n. (Lepidoptera: Cossidae) — bona species // Russian Entomological Journal. Vol.28. No.4. P.458-459.

Yakovlev R.V., Witt Th.J. 2016. Cossidae (Lepidoptera) of Pakistan // Biological Bulletin of Bogdan Chmelnitskiy Melitopol State Pedagogical University. Vol.6. No.2. P.67-76. 